\title{
Occurrence, Molecular Characterization and Phylogenetic Relationship of Aspergillus Species Isolated from Garri Sold in Benue State, North Central, Nigeria
}

\author{
Innocent Okonkwo Ogbonna1 ${ }^{\circledR}$, Innocent Ugochukwu Amai' ${ }^{1}$, Celestine Uzoma Aguoru2 ${ }^{2}$, \\ Dooshima Charity Amai ${ }^{3}$
}

${ }^{1}$ Department of Microbiology, Federal University of Agriculture, Makurdi, Benue State, Nigeria

${ }^{2}$ Department of Botany, Federal University of Agriculture, Makurdi, Benue State, Nigeria

${ }^{3}$ Department of Family Medicine, Federal Medical Centre, Makurdi, Benue State, Nigeria

Email: innocentia09@yahoo.com, innoamai@yahoo.com, celeaguoru@yahoo.com, amaidoosh@gmail.com

How to cite this paper: Ogbonna, I.O., Amai, I.U., Aguoru, C.U. and Amai, D.C. (2021) Occurrence, Molecular Characterization and Phylogenetic Relationship of $A s$ pergillus Species Isolated from Garri Sold in Benue State, North Central, Nigeria. American Journal of Molecular Biology, 11, 100115.

https://doi.org/10.4236/ajmb.2021.114009

Received: August 23, 2021

Accepted: September 21, 2021

Published: September 24, 2021

Copyright $\odot 2021$ by author(s) and Scientific Research Publishing Inc. This work is licensed under the Creative Commons Attribution International License (CC BY 4.0).

http://creativecommons.org/licenses/by/4.0/

\begin{abstract}
Characterization and identification of molds based on cultural and morphological characteristics are often not reliable and frail with limitations. The occurrence of Aspergillus species in garri on sale in markets in Benue State, Nigeria, was studied by molecular techniques. Aspergillus species were isolated and purified on Potato Dextrose Agar. DNA from the purified isolates was extracted using the ZR fungal DNA miniprep and amplified by PCR mix made up of $12.5 \mu \mathrm{L}$ of Taq $2 \mathrm{X}$ Master Mix. Primer sequences for the fungi characterization were internal transcribed spacers ITS 4 and ITS 5. The phylogenetic tree was plotted between the isolated organisms and reference sequences and evolutionary analysis was conducted in MEGA X. Result revealed that one thousand, six hundred and forty-six Aspergilli were isolated comprising of 980 and 666 isolates from the white and yellow garri respectively. Aspergillus flavus, $A$. fumigatus, $A$. niger, $A$. aculeatinus, and $A$. aculeatus were identified. Twenty percent $(20 \%)$ of the strains had aflatoxin $\mathrm{D}$ structural gene, $50 \%$ amplified AFLP and $70 \%$ of the strains expressed AFLQ genes needed for the biosynthesis of aflatoxin B1. Majority of the strains that showed the expression of these structural genes were consistent with Aspergillus flavus. Phylogenetic tree showed a close relationship among the isolates and their most identical sequence in the NCBI database.
\end{abstract}

\section{Keywords}

Aflatoxin, Aspergillus species, Aspergillosis, Garri, Polymerase Chain Reaction (PCR), Benue State 


\section{Introduction}

The genus Aspergillus has significant presence in a variety of ecosystems and different substrates such as the soil, textiles, food and feed [1] [2] [3] [4] [5]. Aspergillus species cause the disease aspergillosis. The disease caused by these filamentous fungi has been a major threat [6]. The human aspergillosis is caused by fungi of the Aspergillus taxonomy. The disease involved a broad range of clinical presentations including the fungus ball of the lung (aspergilloma) [7]. Saprophytic fungi of the Aspergillus genus are a common contaminant of food and soil, and their spores are ubiquitous. It is estimated that approximately 10 million patients are considered at risk of developing invasive aspergillosis each year [8]. The most frequent species involved in human disease is Aspergillus fumigatus, followed by Aspergillus flavus [8].

In addition to the general human aspergillosis, a disease condition produced by molds of the Aspergillus genera, another major issue arising from mold contamination of food and feed is aflatoxicosis. Aflatoxicosis is a pathological condition resulting from the consumption of aflatoxin. Aflatoxins are metabolites of some Aspergillus species that display acute immune and hepatotoxic effects in humans, and very high carcinogenic potential following chronic exposure [9] [10]. Aflatoxins contaminate food/feed and could occur before and after harvest and its occurrence is favored by conditions such as storage, transportation and food processing, even when the best practices are followed [11]. It causes liver cancer: responsible for $5 \%-28 \%$ of liver cancer cases, stunted growth in children, immunosuppression, and decreases resistance to infections [11] [12]. In animals, aflatoxins can lead to liver damage, impaired productivity and reproductive efficiency, and increased susceptibility to diseases. It has been estimated that 7761 out of 10,130 liver cancer cases in Nigeria in 2010 were attributable to aflatoxins [11] [12]. The US Food and Drug Administration (FDA) has set limits of $20 \mu \mathrm{g} / \mathrm{kg}$ for total aflatoxins for human and animals, and $0.5 \mu \mathrm{g} / \mathrm{kg}$ for milk and its products [13]. The Nigeria's National Agency for Food and Drugs Administration and Control (NAFDAC) enforces a standard of $4 \mu \mathrm{g} / \mathrm{kg}$ for ready-to-eat foods and $10 \mu \mathrm{g} / \mathrm{kg}$ for raw food items, for packaged goods and export-bound products [14].

Chemically, aflatoxins are metabolites which are derivative of polyketide and require the formation of hexanoate units in their biosynthesis [15]. Aflatoxin production is mediated by a cascade of structural and some regulatory genes. The biosynthetic pathway of aflatoxin involves different clustered genes, including structural, regular, and unassigned genes [16]. DNA-based detection system is a powerful, quick, reliable and more precise method for detecting aflatoxin and includes polymerase chain reaction (PCR) and the expression of aflatoxin specific genes including aflD (nor-1), aflP (omtA), aflO (omtB), aflQ (ordA), aflR [16] [17] [18].

Aflatoxin production normally starts with the transformation of the starter unit into the first stable metabolite norsolorinic acid (NOR). The nor-1 is the old 
name for aflD and it codes a norsolorinic acid ketoreductase needed to convert 1'-keto group of norsolorinic acid to 1'-hydroxyl group of averantin [19]. Aflatoxin $\mathrm{P}$ gene omtA is an old name for aflP and codes for the enzyme O-methyltransferase A. It functions in the conversion of sterigmatocystin (ST) to O-methylsterigmatocystin (OMST). Another key gene in the aflatoxin biosynthetic pathway is the aflO formerly called omtB. This codes for the enzyme O-methyltransferase $\mathrm{B}$ responsible for the conversion of dihydrodemethylsterigmatocystin (DHDMST) to dihydrosterigmatocystin (DHST). Similarly, aflQ was formerly called ordA. It codes for Oxydoreductase which converts O-methylsterigmatocystin (OMST) to AFB1 and AFG1, dihydro-Omethylsterigmatocystin (DHOMST) to AFB2 and AFG2. Finally, aflR is a transcription activator and regulates aflatoxin biosynthesis [20] [21] [22].

Conventional mold identification in the clinical laboratory relies on microscopic and macroscopic morphological features [23]. Due to the unusual poor sporulation and anti-fungal resistance phenotypes, clinical isolates formerly identified as $A$. fumigatus have been re-identified using multi-locus sequence analysis. DNA-sequencing enabled the identification of "cryptic" species [24]. The success of molecular identification largely depends on the choice of the right primer sequence for the amplification of the DNA. Schoch et al. [25] had evaluated six DNA regions as potential DNA barcodes for fungi by a multi-national, multi-laboratory consortium. They discovered among the regions of the ribosomal cistron, that the internal transcribed spacer (ITS) region has the highest probability of successful identification for the broadest range of fungi, with the most clearly defined barcode gap between inter- and intra-specific variation. They further proposed that ITS be adopted as the primary fungal barcode marker [25]. In the present study, ITS was used as the primer sequence for the amplification of the genes from Aspergillus species.

Garri is a staple food prepared from the roots of cassava (Manihot esculenta Crantz). It is made from peeled, washed, grated, fermented and toasted fresh cassava tuber [26] [27]. Garri is stored and marketed in a ready to eat form [28] [29]. The major biological agents that contaminate and spoil garri are molds, insects and mites [30] [31]. Garri is rich in carbohydrate and therefore suitable for fungal growth. Molds such as Aspergillus, Penicillium, Fusarium, Rhizopus, Cladosporium and Mucor have been associated with garri during storage and distribution [32] [33].

There is information on the occurrence, contamination and distribution of the Aspergillus in garri in many localities of Nigeria and the health implications of consumption of such garri. Several researchers have isolated Aspergillus species from both white and yellow garri [29] [32]-[38]. However, several of these authors did not characterize this major spoilage agent Aspergillus by molecular method.

The present study therefore aimed to determine the occurrence, molecular characterization and phylogenetic relationship of Aspergillus species isolated from 
garri sold in Benue State, North Central, Nigeria. Aspergillus species were isolated and molecularly characterized via DNA amplification and sequencing. Amplification of specific genes required for aflatoxin B1 production were also carried out.

\section{Materials and Methods}

\subsection{Preparation of Potato Dextrose Broth for Molecular Analysis}

Briefly, the Potato Dextrose broth (Himedia Laboratories ${ }^{(\mathrm{R})}$ ) was prepared by measuring and dissolving $39 \mathrm{~g}$ in $1000 \mathrm{~mL}$ of distilled water, and filtering through the Whatman number 1 filter paper. This was sterilized by autoclaving at a temperature of $121^{\circ} \mathrm{C}$ for 15 minutes using saturated steam of 15 psi of pressure. This was allowed to cool to $45^{\circ} \mathrm{C}-50^{\circ} \mathrm{C}$ and supplemented with chloramphenicol $(0.05 \mathrm{~g} / \mathrm{L})$ before dispensing into the already sterilized bottles. Thereafter, the pure isolates were inoculated into the broth and incubated for 48 72 hours and the growth was used for molecular analysis.

\subsection{Extraction of Fungal DNA}

The DNA from the purified isolate was extracted using the ZR fungal DNA miniprep (Zymo Research Cat Number: D6005). Two milliliters of the fungal suspension were added to Zymo Research Bashing ${ }^{\mathrm{TM}}$ lysis tube. This was followed by the addition of $750 \mu \mathrm{L}$ lysis solution. This was secured in a bead fitted with 2 $\mathrm{mL}$ tube holder assembly and processed at maximum speed $(10,000 \mathrm{x} \mathrm{g})$ for five minutes. Centrifugation of the Zymo Research Bashing bead ${ }^{\mathrm{TM}}$ lysis tube in a microcentrifuge at $>10,000 \mathrm{x}$ g for 1 minute was done. Thereafter, $400 \mu \mathrm{L}$ supernatant was transferred to a Zymo-Spin IV $^{\mathrm{TM}}$ Spin Filter (orange top) in a collection tube and centrifuged at $7000 \mathrm{x} g$ for 1 minute. In addition, $1200 \mu \mathrm{L}$ of fungal DNA Binding Buffer was added to the filtrate in the collection tube. Then, 800 $\mu \mathrm{L}$ of the mixture was transferred to a Zymo-Spin ${ }^{\mathrm{TM}}$ IIC column in a collection tube and centrifuged at $10,000 \mathrm{x} g$ for 1 minute. The flow through from the collection tube was discarded and the above step repeated. Also, $200 \mu \mathrm{L}$ DNA pre-washed buffer was added to the Zymo-Spin ${ }^{\mathrm{TM}}$ IIC column in new collection tube and centrifuged at 10,000 x $\mathrm{g}$ for 1 minute. Then, $500 \mu \mathrm{L}$ fungal DNA wash buffer was added to the Zymo-Spin ${ }^{\mathrm{TM}}$ IIC column and centrifuged at 10,000 x $\mathrm{g}$ for 1 minute. Finally, the Zymo-Spin ${ }^{\mathrm{TM}}$ IIC column was transferred to a clean 1.5 $\mathrm{mL}$ microcentrifuge tube and $100 \mu \mathrm{L}$ DNA elution buffer added directly to the column matrix. This was centrifuged at $10,000 \times \mathrm{g}$ for 30 seconds to elute the DNA.

\subsection{Electrophoresis for DNA and Polymerase Chain Reaction}

One gram (1 g) of agarose for DNA and $2 \mathrm{~g}$ of agarose for PCR were measured. Agarose powder was mixed with $100 \mathrm{~mL} 1 \mathrm{xTAE}$ in a microwavable flask. These were microwaved for 2 minutes until the agarose was completely dissolved but the solution was not allowed to overboil, as some of the buffer would evaporate 
and thus alter the final percentage of agarose in the gel. The agarose solution was allowed to cool to $50^{\circ} \mathrm{C}$ for 5 minutes. Then, $10 \mu \mathrm{L} \mathrm{EZ} \mathrm{vision} \mathrm{DNA} \mathrm{stain} \mathrm{was}$ added. The agarose gel was poured into a gel tray with the well comb in place. The newly poured gel was placed at $4^{\circ} \mathrm{C}$ for 15 minutes.

\section{Loading Samples and Running the Agarose Gel}

The loading buffer was added to each of the DNA samples. The agarose gel was placed into the gel box once it solidified. The gel box was filled with 1xTAE until gel was covered. Then, a molecular weight ladder was carefully loaded into the first lane of the gel. Also, the samples were carefully loaded into additional wells of the gel. The gel was run at 150 Volts for 1 hour. The power was then turned off, the electrodes disconnected and gel carefully removed from the gel box. The DNA fragments was visualized under the ultra violet (UV) transilluminator.

\subsection{Polymerase Chain Reaction Mix Components}

The PCR mix was made up of $12.5 \mu \mathrm{L}$ of Taq 2X Master Mix (M0270, New England Biolabs); $1 \mu \mathrm{L}$ each of $10 \mu \mathrm{M}$ forward and reverse primer; $2 \mu \mathrm{L}$ of DNA template and then made up with $8.5 \mu \mathrm{L}$ Nuclease free water. Primer sequences for fungi characterization:

Forward ... ITS4: TCCTCCGCTTATTGATATGC

Reverse ... ITS5: GGAAGTAAAAGTCGTAACAAGG

\subsubsection{Cycling Conditions for Gene Specific Primers (AFLD and AFLP)}

The initial denaturation at $94^{\circ} \mathrm{C}$ for five minutes was done, followed by 36 cycles of denaturation at $94^{\circ} \mathrm{C}$ for thirty seconds. This was thereafter followed by annealing at $55^{\circ} \mathrm{C}$ for thirty seconds and elongation at $72^{\circ} \mathrm{C}$ for forty-five seconds. In addition, a final elongation was achieved at $72^{\circ} \mathrm{C}$ for seven minutes and was held at a temperature of $10^{\circ} \mathrm{C}$.

\subsubsection{Cycling Conditions for Gene Specific Primer (AFLQ)}

The initial denaturation for five minutes at $94^{\circ} \mathrm{C}$ was done. This was followed by denaturation by thirty-six cycles for thirty seconds at $94^{\circ} \mathrm{C}$, and annealing for thirty seconds at $50^{\circ} \mathrm{C}$; then elongation for forty-five seconds at $72^{\circ} \mathrm{C}$. These were followed by the final elongation for seven minutes at $72^{\circ} \mathrm{C}$ and a holding temperature at $10^{\circ} \mathrm{C}$. For the cycling of gene specific primers, negative and positive control molds were Penicillium species (non-aflatoxigenic) and A. flavus previously known to produce aflatoxin respectively.

\subsection{Phylogenetic Tree Analysis}

The evolutionary history was inferred by using the Maximum Likelihood method and [39] model. Initial tree for the heuristic search was obtained automatically by applying Neighbor-Join and BioNJ algorithms to a matrix of pairwise distances estimated using the Maximum Composite Likelihood (MCL) approach, and then selecting the topology with superior log likelihood value. The tree was 
drawn to scale, with branch lengths measured in the number of substitutions per site. Evolutionary analyses were conducted in MEGA X [40].

\section{Results}

Molecular characterization of Aspergillus species with potential of causing aflatoxin contamination of garri in selected Local Government Areas (LGA) of Benue State, North Central Nigeria is presented in Table 1. The ITS gene amplified all the Aspergillus isolates at between 600 to 700 base pair (bp). A. flavus was most notable fungi in aflatoxin causation identified in samples from four (4) LGA including Oju, Buruku, Vandeikya and Ushongo, Prevalence and distribution of Aspergillus species in Garri in 12 LGAs of Benue State is shown in Table 2. Guma LGA had the highest $A$. fumigatus isolate (49 in white garri and 36 in yellow garri). Buruku had no $A$. fumigatus isolate. Vandeikya LGA had the highest $A$. niger isolates of 54 in white garri and 35 in yellow garri. Okpokwu had the least isolate of $A$. niger of 12 in white garri. Ogbadigbo LGA had the least $A$. niger isolates of 6 in yellow garri. $A$. aculeatinus was isolated only in white garri from Okpokwu and Gboko LGA. Oju LGA had the highest A. flavus isolates of 51 from white garri and 33 isolates from yellow garri. Kwande LGA had the least isolates of $A$. flavus of 3 in white garri and 4 in yellow garri. Konshisha LGA had the least isolates of Aspergillus. Aspergillus aculeatus was also not predominant across the LGAs. Table 3 shows the percentage distribution of Aspergillus in the studied population with Aspergillus niger having the highest distribution across the LGAs and Aspergillus aculeatus having the least distribution, especially in yellow garri. Aspergillus aculeatinus was not found in yellow garri across the LGAs.

Table 1. Molecular characterization of Aspergillus species contamination of garri in selected LGA in Benue State.

\begin{tabular}{|c|c|c|c|c|c|}
\hline Sample & Location/LGA & $\begin{array}{c}\text { Aspergillus } \\
\text { identified }\end{array}$ & Strain & $\begin{array}{l}\text { Pairwise } \\
\text { Identity }\end{array}$ & $\begin{array}{c}\text { NCBI Accession } \\
\text { number }\end{array}$ \\
\hline 1 & Gboko & Aspergillus aculeatinus & B2819 & 89.30 & MK204521 \\
\hline 2 & Ogbadigbo & A. niger & LS1614 & 94.30 & KT335957 \\
\hline 3 & Oju & A. flavus & BRM051244 & 99.50 & MK461562 \\
\hline 4 & Buruku & A. flavus & JN-YG-3-5 & 99.00 & MG554231 \\
\hline 5 & Guma & A. flavus & SMLF30 & 99.00 & MGG840796 \\
\hline 6 & Vandeikya & A. flavus & BRM051244 & 99.30 & MK461562 \\
\hline 7 & Makurdi & A. flavus & SMLF30 & 99.80 & MK281555 \\
\hline 8 & Otukpo & A. aculeatus & AN5 & 98.10 & KY859793 \\
\hline 9 & Ushongo & A. flavus & CBS & 98.20 & MH864264 \\
\hline 10 & Okpokwu & A. aculeatus & JO6 & 95.90 & EU645733 \\
\hline
\end{tabular}


Table 2. Prevalence and distribution of Aspergillus species in garri in 12 LGA in benue state.

\begin{tabular}{cccccccccccccc}
\hline \multirow{2}{*}{ LGA } & \multicolumn{1}{c}{ A. fumigatus } & \multicolumn{1}{c}{ A.niger } & A. aculeatinus & \multicolumn{2}{c}{ A. flavus } & A. aculeatus & Total & $\%$ \\
\cline { 2 - 12 } & WG & YG & WG & YG & WG & YG & WG & YG & WG & YG & & \\
\hline Makurdi & 32 & 21 & 34 & 10 & - & - & 6 & 6 & 6 & - & 115 & 6.99 \\
Ogbadigbo & 20 & 24 & 34 & 6 & - & - & 10 & 8 & - & - & 102 & 6.20 \\
Kwande & 25 & 18 & 32 & 14 & - & - & 3 & 4 & - & - & 96 & 5.83 \\
Ushongo & 24 & 30 & 16 & 22 & - & - & 24 & 8 & - & - & 124 & 7.53 \\
Vandeikya & 32 & 24 & 54 & 35 & - & - & 34 & 18 & - & - & 197 & 11.97 \\
Oju & 12 & 31 & 28 & 14 & - & - & 51 & 33 & - & - & 169 & 10.27 \\
Buruku & - & - & 24 & 30 & - & - & 30 & 24 & - & - & 108 & 6.56 \\
Guma & 49 & 36 & 18 & 20 & - & - & 32 & 12 & - & - & 167 & 10.15 \\
Okpokwu & 29 & 32 & 12 & 16 & 8 & - & 22 & 10 & 21 & 14 & 164 & 9.96 \\
Gboko & 16 & 20 & 42 & 18 & 4 & - & 32 & 18 & - & - & 150 & 9.11 \\
Otukpo & 14 & 10 & 46 & 18 & 0 & - & 20 & 15 & 28 & 15 & 166 & 10.09 \\
Konshisha & 20 & 14 & 36 & 18 & 0 & - & - & - & - & - & 88 & 5.34 \\
Total & 273 & 260 & 376 & 221 & 12 & - & 264 & 156 & 55 & 29 & 1646 & 100 \\
\hline
\end{tabular}

KEY: A: Aspergillus; WG: White garri; YG: Yellow garri.

Table 3. Total distribution of Aspergillus species isolated from the garri.

\begin{tabular}{cccc}
\hline Isolate & Type of Garri & Frequency & Percentage \\
\hline Aspergillus fumigatus & White & 273 & 16.58 \\
Aspergillus fumigatus & Yellow & 260 & 15.80 \\
Aspergillus niger & White & 376 & 22.84 \\
Aspergillus niger & Yellow & 221 & 13.43 \\
Aspergillus aculeatinus & White & 012 & 0.73 \\
Aspergillus aculeatinus & Yellow & 000 & 0.00 \\
Aspergillus flavus & White & 264 & 16.04 \\
Aspergillus flavus & Yellow & 156 & 9.48 \\
Aspergillus aculeatus & White & 055 & 3.34 \\
Aspergillus aculeatus & Yellow & 029 & 1.76 \\
Total & & 1646 & 100 \\
\hline
\end{tabular}

The agarose gel picture of the amplified DNA extracted from 10 fungal $A s$ pergilli strains is shown in Figure 1. The lane $\mathrm{M}$ was $200 \mathrm{bp}$ whereas the highest point was 1350 base pair (bp). Most of the isolates contained genes that fell within 600 to $800 \mathrm{bp}$. The strains involved were 1 from Gboko (Aspergillus aculeatinus); strain 2 from Ogbadigbo (Aspergillus niger); strain 3 from Oju (Aspergillus flavus); strain 4 from Buruku (Aspergillus flavus); strain 5 from Guma (Aspergillus flavus); strain 6 from Vandeikya (Aspergillus flavus); strain 7 from Makurdi (Aspergillus flavus); strain 8 from Otukpo (Aspergillus aculeatinus); strain 9 from Ushongo (Aspergillus flavus) and strain 10 from Okpokwu (Aspergillus aculeatus).

Figure 2 presents the agarose gel picture of the amplification of AFLP struc- 
tural gene at $650 \mathrm{bp}$. The marker lane is $50 \mathrm{bp}$ molecular weight. Out of the 10 fungal strains loaded in the agarose comb, five (5) (50\%) of the strains showed clear amplification at $650 \mathrm{bp}$ and showed possession of AFLP structural genes. The strains were Aspergillus flavus (from Buruku), Aspergillus flavus (from Vandeikya), Aspergillus flavus (from Ushongo), Aspergillus flavus (from Guma) and Aspergillus flavus (from Makurdi). Aspergillus aculeatinus (from Gboko), Aspergillus niger (from Ogbadigbo), Aspergillus flavus (from Oju), Aspergillus aculeatus (from Otukpo) and Aspergillus aculeatus (from Okpokwu) respectively have no AFLP genes in them.

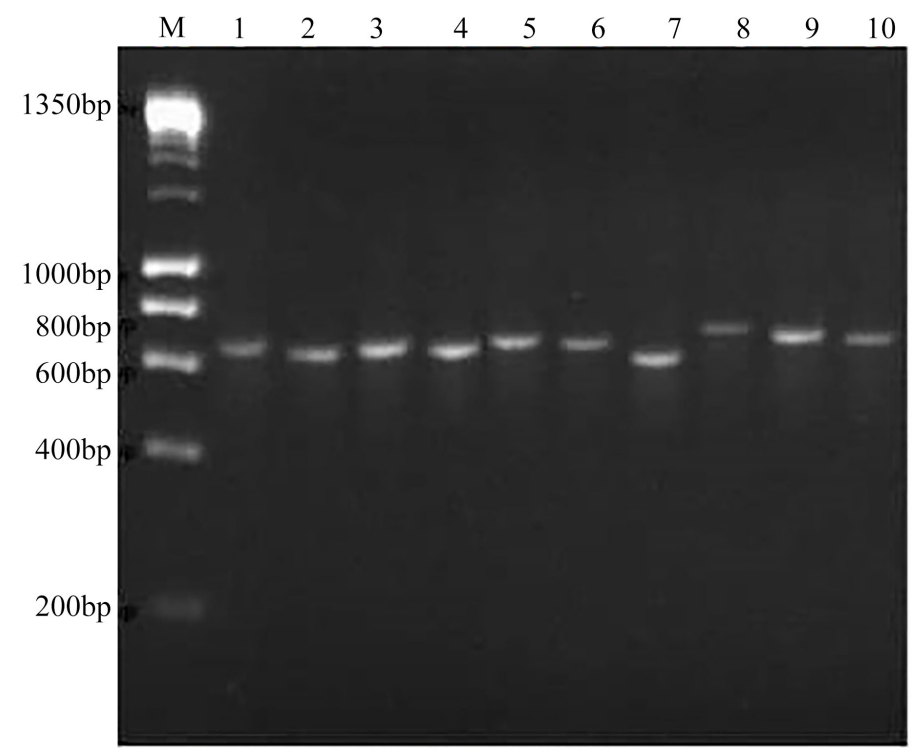

Amplification results of the Fungi ITS region

Figure 1. Gel picture for the amplification of Fungi at ITS region.

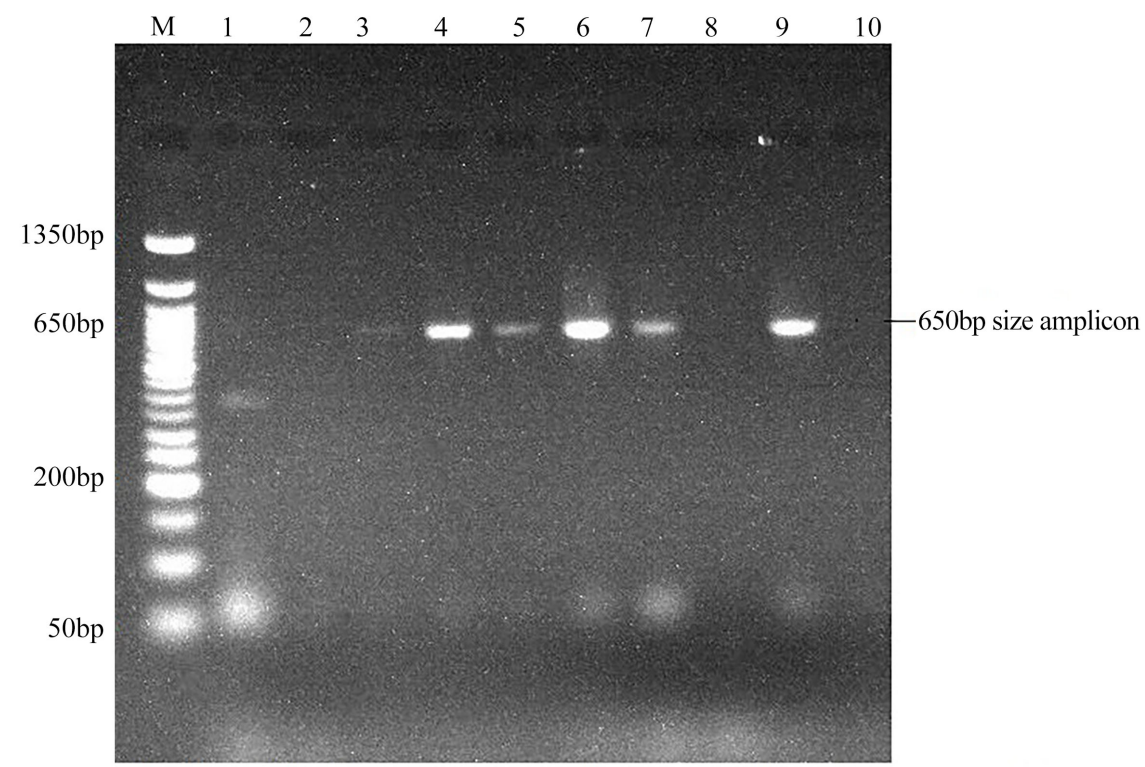

Gel image showing amplification of AFLP gene at 650bp. Lane $\mathrm{M}=50 \mathrm{bp}$ molecular weight ladder

Figure 2. Gel image showing amplification of AFLP gene at $650 \mathrm{bp}$. 
The gel picture for the amplification of AFLD structural gene at $750 \mathrm{bp}$ is shown in Figure 3. The lane $M=50 \mathrm{bp}$ molecular weight. Out of the 10 fungal strains loaded in the gel, only two (2) were amplified showing $20 \%$ of the strains having aflatoxin $\mathrm{D}$ structural gene.

Figure 4 shows the gel amplification of AFLQ gene at $450 \mathrm{bp}$. The lane $\mathrm{M}=$ $50 \mathrm{bp}$ molecular weight maker. Out of the 10 fungal strains loaded in the agarose comb, seven (7) (70\%) of the strains showed amplification at $450 \mathrm{bp}$ and showed possession of AFLQ structural genes. The Aspergillus flavus (from Oju), Aspergillus flavus (from Buruku), Aspergillus flavus (from Guma), Aspergillus flavus (from Vandeikya), Aspergillus aculeatus (from Otukpo), Aspergillus flavus (from Ushongo) and Aspergillus aculeatus (from Okpokwu) show the presence of the AFLQ gene at 450 bp; while Aspergillus aculeatinus (from Gboko), Aspergillus niger (from Ogbadigbo) and Aspergillus flavus (from Makurdi) show no presence of the gene AFLQ at $450 \mathrm{bp}$.

Genetic relatedness of the isolates studied using the method of Maximum Likelihood showed close phylogenetic relationship amongst the Aspergillus species (Figure 5).

\section{Discussion}

Study on the occurrence, molecular characterization and phylogenetic relationship of Aspergillus species isolated from garri points to a potential food safety problem arising from the consumption should the product be contaminated with aflatoxigenic or invasive species. In the present study, out of one thousand six hundred and forty-six Aspergillus isolates, the isolates with related morphological features were selected together. Out of these grouping, ten (10) fungi

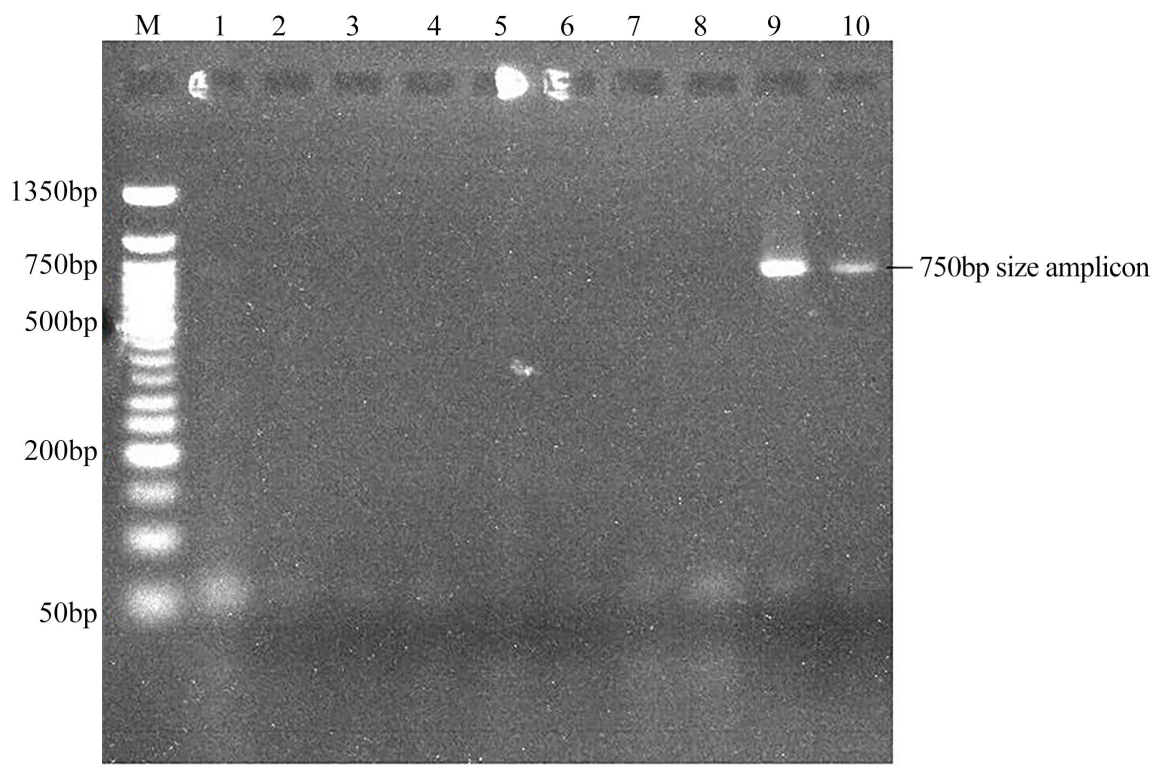

Gel image showing amplification of AFLD gene at 750bp

Lane $\mathrm{M}=50 \mathrm{bp}$ molecular weight ladder

Figure 3. Gel image showing amplification of AFLD gene at $750 \mathrm{bp}$. Lane $\mathrm{M}=50 \mathrm{bp}$ molecular weight ladder. 


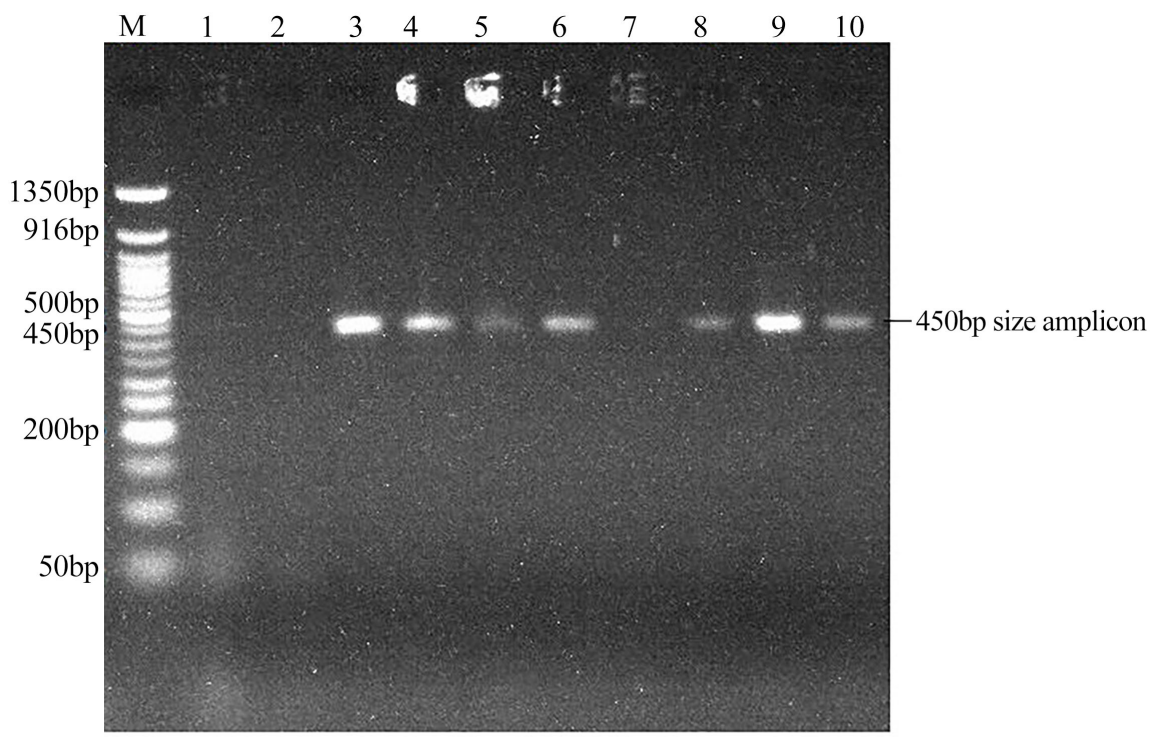

Gel image showing amplification of AFLQ gene at 450bp. Lane $\mathrm{M}=50 \mathrm{bp}$ molecular weight ladder

Figure 4. Gel image for the amplification of AFLQ gene at $450 \mathrm{bp}$. Lane $=50 \mathrm{bp}$ molecular weight ladder.

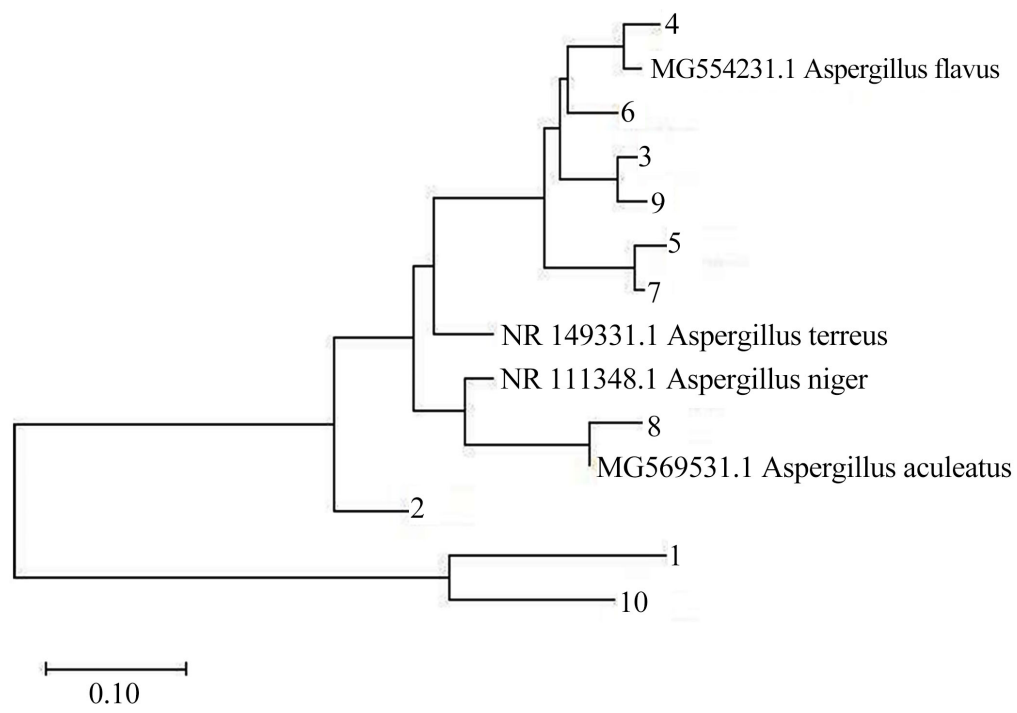

Figure 5. Phylogenetic Relationship of the Aspergillus species. KEY: 1. Aspergillus aculeatinus, 2: Aspergillus niger, 3: Aspergillus flavus, 4: Aspergillus flavus; 5: Aspergillus flavus; 6: Aspergillus flavus, 7: Aspergillus flavus; 8: Aspergillus aculeatus; 9: Aspergillus flavus; 10: Aspergillus aculeatus.

(representing each group) were studied for aflatoxigenic producing potentials using molecular approaches.

The occurrence of Aspergillus species isolated from garri sold in Benue State, North Central, Nigeria showed the presence of A. flavus, A. fumigatus, A. niger, $A$. aculeatinus, and $A$. aculeatus. Aspergillus niger obtained from white garri was the highest species load obtained in the present study pointing to the ubiquitous habit of A. niger. Aspergillus fumigatus that causes invasive aspergillosis [8] was the second highest isolate number. This was followed by $A$. flavus known to 
produce aflatoxins that cause a lot of damages to humans and their livestock [9] [10] [11] [12]. Previous studies in Bayelsa, Kogi, and Benue States, all in Nigeria, have also confirmed the isolation of Aspergillus species, though none of these studies characterized the organisms to the species levels [36] [37] [41]. Of all the isolated species of the present study, A. flavus was most notable fungus in aflatoxin production. World Health Organization, WHO [42] estimated that 5\% $28 \%$ of liver cancer cases are caused by aflatoxin. Aspergillus fumigatus is the predominant Aspergillus responsible for the causation of invasive aspergillosis as it has been the most common species recovered from these cases of invasive aspergillosis. The next most commonly recovered species are A. flavus, A. niger and A. terreus [7].

The Aspergillus aculeatinus and A. aculeatus were the least isolated species in the present study. According to Gautier et al. [43], these groups of fungi were not known previously, and the cultural and traditional methods of characterization were not able to categorize and differentiate them from the other AspergilIus strains, but have been successfully characterized by use of DNA sequence. They belong to the group of "cryptic" Aspergillus species which were not known previously. Gautier et al. [43] had noted that, these organisms have been a major cause of life-threatening infections, especially in individuals whose immunities have been compromised. These organisms belong to the Nigri section of the Aculeatus clad, and included Aspergillus aculeatinus, A. aculeatus, A. indologenus, $A$. japonicus, $A$. uvarum [43]. They cause aspergillosis, with various clinical presentations such as aspergilloma also known as fungus ball of the lung, asthma exacerbations and severe asthma with fungal sensitization, allergic bronchopulmonary aspergillosis, cutaneous and wound infections, osteoarticular infections, chronic pulmonary aspergillosis, chronic invasive and granulomatous sinusitis, Aspergillus bronchitis, invasive pulmonary aspergillosis, and disseminated aspergillosis [6] [7]. These organisms have been reported somewhere to be very resistant to antifungal agents [44].

The identification of mold by conventional clinical laboratory methods use microscopic and macroscopic morphological features [23]. This method has its attendant limitations. For instance, due to the unusual poor sporulation and anti-fungal resistance phenotypes, clinical isolates formerly identified as A. fumigatus have been re-identified using multi-locus sequence analysis. "Cryptic" species identification has been made possible by DNA-sequencing [24]. Polymerase chain reaction (PCR) a molecular technique was adopted in the present study and ITS primers used. Internal Transcribed Spacer (ITS) used as primer sequences in the present study, has been proposed to be adopted as the primary fungal barcode marker having highest probability of successful identification for the broadest range of fungi [25]. Internal Transcribed Spacer (ITS) combines the highest resolving power for discriminating closely related species with a high PCR and sequencing success rate across wide range of fungi [25].

Detection of aflatoxin specific structural and regulatory genes including AFLD, 
AFLP and AFLQ by polymerase chain reaction was used for the differentiation of aflatoxin producing and non-aflatoxin producing isolates. Aspergillus. flavus from Ushongo and $A$. aculeatus from Okpokwu amplified AFLD gene. There was a clear amplification of AFLP by $A$. flavus. The amplification of AFLP structural gene at $650 \mathrm{bp}$ by the strains of Aspergillus flavus from the study area shows their potential aflatoxin B1 biosynthetic ability. Aspergillus flavus expressed the aflatoxin specific genes AFLP, AFLD and AFLQ. Aflatoxin D gene (aflD) codes a norsolorinic acid ketoreductase which converts 1'-keto group of norsolorinic acid to 1'-hydroxyl group of averantin [19]. The aflP codes for the enzyme O-methyltransferase A which converts sterigmatocystin (ST) to O-methylsterigmatocystin (OMST) [20] [21] [22]. The aflQ codes for Oxydoreductase which converts O-methylsterigmatocystin (OMST) to AFB1 and AFG1, dihydro-Omethylsterigmatocystin (DHOMST) to AFB2 and AFG2 [20] [21] [22]. The expression of genes AFLP, AFLD and AFLQ in the present study is consistent with the reports of Scherm et al. [17] and Sohrabi and Taghizadeh [16] in the molecular detection of aflatoxigenic molds. The use of PCR amplification of genes involved in aflatoxin biosynthesis had been previously used to differentiate aflatoxigenic from non-aflatoxgenic molds [15] [16] [18]. Scherm et al. [17] had previously demonstrated the use of reverse transcription polymerase chain reaction for the differentiation of aflatoxin and non-aflatoxin producing isolates of Aspergillus flavus and $A$. parasiticus. Using specific primers based on conserved sequences of structural genes aflD, aflG, aflH, aflI, aflK, aflM, aflO, aflP, and aflQ and regulatory genes aflR and aflS, needed for the biosynthesis of aflatoxin B1, Scherm et al. [17] noted the expression profile of three genes aflP, aflD, and aflO. These genes $(a f l P$, aflD, and $a f l O)$ were consistently correlated with the capacity of the organisms' ability to produce aflatoxin B1 or not.

The phylogenetic tree plotted between the isolated organisms and reference sequences from the NCBI was done, and the outcome showed a close relationship between the isolates and their most identical sequence in the NCBI database. This tree formed three major claudes with most of the isolates clustering with Aspergillus flavus in the first cluster. Aspergillus flavus from Buruku LGA formed the closest cluster with the reference sequence of Aspergillus flavus MG554231 and Aspergillus flavus from Vandeikya LGA was closely related to this cluster having a 0.09 genetic distance apart. The cluster was closely related to a branch formed between A. flavus from Oju LGA and $A$. flavus from Ushongo, of which both of them have a 0.03 distance apart. Again, a member of the cluster is the most distant group that comprise a cluster between Aspergillus flavus from Guma and Aspergillus flavus from Makurdi LGA that also has a 0.03 genetic distance apart. Another claude is Aspergillus aculeatus which clustered with the reference sequence of MG569531 of Aspergillus aculeatus, while the A. niger stands out as an outgroup of these claudes. However, the most distant group is the group consisting of a cluster between Aspergillus aculeatinus from Gboko LGA and $A$. aculeatus from Okpokwu, and this group recorded a 0.28 genetic distance apart. 


\section{Conclusion}

DNA sequence analysis showed that Aspergillus species isolated were Aspergillus flavus, $A$. fumigatus, $A$. niger, $A$. aculeatinus, and $A$. aculeatus with $A$. niger being the most abundant. Aflatoxin specific structural genes including AFLD, AFLP and AFLQ which code for enzymes that perform key functions in aflatoxin B1 biosynthetic pathway were expressed by Aspergillus flavus. Synthesis of aflatoxin in garri, a ready-to-eat food product could have negative health implications to consumers. Phylogenetic tree showed a close relationship among the isolates.

\section{Acknowledgements}

Mrs. A Nwosu is hereby acknowledged for her laboratory services.

\section{Conflicts of Interest}

The authors declare no conflicts of interest regarding the publication of this paper.

\section{References}

[1] Klich, M.A., Tiffany, L.H. and Knaphus, G. (1992) Ecology of the Aspegilli of Soils and Litter. In: Benneth, J.W. and Klich, M.A., Eds., Aspergillus. Biology and Industrial Applications, Butterworth Heineman, Boston, 329-354.

[2] Klich, M.A. (2002) Biogeography of Aspergillus Species in Soil and Litter. Mycolgia, 94, 21-27. https://doi.org/10.2307/3761842

[3] Perrone, G., Susca, A., Cozzi, G., Ehrlich, K., Varga, J., Frisvad, J.C., Meijer, M., Noonim, P., Mahakarnchanakul, W. and Samson, R.A. (2007) Biodiversity of $A s$ pergillus Species in Some Important Agricultural Products. Studies in Mycology, 59, 53-66. https://doi.org/10.3114/sim.2007.59.07

[4] Klich, M.A. (2009) Health Effects of Aspergillus in Food and Air. Toxicology and Industrial Health, 25, 657-667. https://doi.org/10.1177/0748233709348271

[5] Pitt, J.I. and Hocking, A.D. (2009) Fungi and Food Spoilage. Springer, Boston.

[6] Kullberg, B.J. and Oude-Lashof, A.M.L. (2002) Epidemiology of Opportunistic Invasive Mycoses. European Journal of Medical Research, 7, 183-191. https://doi.org/10.1007/978-0-387-92207-2

[7] Walsh, T.J., Anaissie, E.J., Denning, D.W., Herbrecht, R., Kontoyiannis, D.P., Marr, K.A., et al. (2008) Treatment of Aspergillosis: Clinical Practice Guidelines of the Infectious Diseases Society of America. Clinical Infectious Diseases, 46, 327-360. https://doi.org/10.1086/525258

[8] The Fungal Infection Trust (2011) How Common Are Fungal Diseases? Fungal Research Trust 20th Anniversary Meeting, London, 18 June 2011, Updated December 2012.

[9] Eaton, D.L. and Gallagher, E.P. (1994) Mechanisms of Aflatoxin Carcinogenesis. Annual Review of Pharmacology and Toxicology, 34, 135-172. https://doi.org/10.1146/annurev.pa.34.040194.001031

[10] Ellis, W.O., Smith, J.P., Simpson, B.K., Oldham, J.H. and Scott, P.M. (1991) Aflatoxins in Food: Occurrence, Biosynthesis, Effects on Organisms, Detection, and 
Methods of Control. Critical Reviews in Food Science and Nutrition, 30, 403-439. https://doi.org/10.1080/10408399109527551

[11] Ogiehor, I.S. and Ikenebomeh, M.J. (2004) Antimicrobial Effects of Sodium Benzoate on the Growth, Survival and Aflatoxin Production Potentials of Some Species of Aspergillus in Garri during Storage. Pakistan Journal of Nutrition, 3, 300-303. https://doi.org/10.3923/pjn.2004.300.303

[12] Abt Associates, Inc., Aflatoxin Country Assessment for Nigeria (2012) Aflatoxin Contamination and Potential Solutions for Its Control in Nigeria, A Summary of the Country and Economic Assessment. The Aflatoxin Stakeholder Workshop, Dar es Salaam, 3-4 December 2012, 1-34.

[13] FDA (U.S. Food and Drug Administration) (2009) Compliance Policy Guides: Action Levels for Aflatoxin in Animal Feed.

[14] Batagarawa, U.S., Dangora, D.B. and Haruna, M. (2015) Aflatoxin Contamination in Some Selected Grains, Feeds and Feed Ingredients in Katsina and Zaria Metropolis. Annals of Experimental Biology, 3, 1-7.

[15] Roze, L.V., Hong, S.-Y. and Linz, J.E. (2013) Aflatoxin Biosynthesis: Current Frontiers. Annual Review of Food Science and Technology, 4, 293-311. https://doi.org/10.1146/annurev-food-083012-123702

[16] Sohrabi, N. and Taghizadeh, M. (2018) Molecular Identification of Aflatoxigenic Aspergillus Species in Feedstuff Samples. Current Medical Mycology, 4, 1-6. https://doi.org/10.18502/cmm.4.2.66

[17] Scherm, B., Palomba, O., Serra, D., Marcello, A. and Migheli, Q. (2005) Detection of Transcripts of the Aflatoxin Genes aflD, aflO, and aflP by Reverse TranscriptionPolymerase Chain Reaction Allows Differentiation of Aflatoxin-Producing from Aflatoxin Non-Producing Isolates of Aspergillus flavus and Aspergillus parasiticus. International Journal of Food Microbiology, 98, 201-210.

https://doi.org/10.1016/j.ijfoodmicro.2004.06.004

[18] Rahimi, S., Sohrabi, N., Ebrahimi, M.A., Tebyanian, M., Morteza, Zadeh, T. and Rahimi, S. (2016) Application of PCR in the Detection of Aflatoxinogenic and Nonaflatoxinogenic Strains of Aspergillus flavus Group of Cattle Feed Isolated in Iran. Journal of Molecular Biology Research, 6, 121-128. https://doi.org/10.5539/jmbr.v6n1p121

[19] Zhou, R. and Linz, J.E. (1999) Enzymatic Function of the Nor-1 Protein in Aflatoxin Biosynthesis in Aspergillus parasiticus. Applied and Environmental Microbiology, 65, 5639-5641. https://doi.org/10.1128/AEM.65.12.5639-5641.1999

[20] Yu, J., Chang, P.-K., Ehrlich, K.C., Cary, J.W., Bhatnagar, D., Cleveland, T.E., Payne, C.A., Linz, J.E., Woloshuk, C.P. and Bennett, J.W. (2004) Clustered Pathway Genes in Aflatoxin Biosynthesis. Applied and Environmental Microbiology, 70, 1253-1262. https://doi.org/10.1128/AEM.70.3.1253-1262.2004

[21] Ehrlich, K., Yu, J. and Cotty, P. (2005) Aflatoxin Biosynthesis Gene Clusters and Flanking Regions. Journal of Applied Microbiology, 99, 518-527. https://doi.org/10.1111/j.1365-2672.2005.02637.x

[22] Cary, J.W., Ehrlich, K.C., Bland, J.M. and Montalbano, B.G. (2006) The Aflatoxin Biosynthesis Cluster Gene, aflX, Encodes an Oxidoreductase Involved in Conversion of Versicolorin A to Demethylsterigmatocystin. Applied and Environmental Microbiology, 72, 1096-1101. https://doi.org/10.1128/AEM.72.2.1096-1101.2006

[23] de Hong, G., Guarro, J., Gene, J. and Figueras, M. (2000) Atlas of Clinical Fungi. 2nd Edition, Centraalbureau voor Schimmelcultures, Utrecht.

[24] Balajee, S.A., Nickle, D., Varga, J. and Marr, K.A. (2005) Aspergillus lentulus sp. 
Nov., a New Sibling Species of A. fumigatus. Eukaryot Cell, 4, 625-632. https://doi.org/10.1128/EC.4.3.625-632.2005

[25] Schoch, C.L., Seifert, K.A., Huhndorf, S., Robert, V., Spouge, J.L., Levesque, C.A., Chen, W. and Fungal Barcoding Consortium (2012) Nuclear Ribosomal Internal Transcribed Spacer (ITS) Region as a Universal DNA Barcode Marker for Fungi. Proceedings of the National Academy of Sciences of the United States of America, 109, 6241-6246. https://doi.org/10.1073/pnas.1117018109

[26] Ernesto, M., Cardoso, A.P, Cliff, J. and Bradbury, J.H. (2000) Cyanogens in Cassava Flour and Roots and Urinary Thiocyanate Concentration in Mozambique. Journal of Food Composition and Analysis, 13, 1-12. https://doi.org/10.1006/jfca.1999.0847

[27] Oluwole, O.B., Olatunji, O.O. and Odunfa, S.F. (2004) A Process Technology for Conversion of Dried Cassava Chips into "Garri". Nigerian Food Journal, 22, 65-73. https://doi.org/10.4314/nifoj.v22i1.33570

[28] Asegbeloyin, J.N. and Onyimonyi, A.E. (2007) The Effect of Different Processing Methods on the Residual Cyanides of 'Gari'. Pakistan Journal of Nutrition, 6, 163-166. https://doi.org/10.3923/pjn.2007.163.166

[29] Ogiehor, I.S., Ikenebomeh, M.J. and Ekundayo, A.O. (2007) The Bioload and Aflatoxin Content of Market Garri from Some Selected States in Southern Nigeria: public Health Significance. African Health Sciences, 7, 223-227.

[30] Igbeka, J.C. (1987) Stimulation of Moisture Profile in Stored Garri. Journal of Food and Agriculture, 1, 5-9.

[31] Ogiehor, I.S., Ekundayo, A.O. and Okwu, G.I. (2005) Shell Stability of Agidi Produced from Maize (Zea mays) and the Effects of Sodium Benzoate Treatment in Combination with Low Temperature Storage. African Journal of Biotechnology, 4, 738-743.

[32] Ekundayo, C.A. (1984) Microbial Spoilage of Packaged Garri in Storage. Microbiology Letters, 23, 271-278.

[33] Ogugbue, C.J., Mbakwem-Aniebo, C. and Akubuenyi, F. (2011) Assessment of Microbial Air Contamination of Post Processed Garri on Sale in Markets. African Journal of Food Science, 5, 503-512.

[34] Amadi, J.E. and Adebola, M.O. (2008) Effect of Moisture Content and Storage Conditions on the Storability of Garri. African Journal of Biotechnology, 7, 4591-4594.

[35] Aguoru, C.U., Onda, M.A., Omoni, V.T. and Ogbonna, I.O. (2014) Characterization of Moulds Associated with Processed Garri Stored for 40 Days at Ambient Temperature in Makurdi, Nigeria. African Journal of Biotechnology, 13, 673-677. https://doi.org/10.5897/AJB2013.12187

[36] Lawani, E.U, Alade, T. and Pelessai, G. (2015) The Mycological Content of Ready to Eat Garri in Amassom, Bayelsa State. African Journal of Food Science, 9, 51-58. https://doi.org/10.5897/AJFS2014.1247

[37] Ogbonna, I.O., Agbowu, B.I. and Agbo, F. (2017) Proximate Composition, Microbiological Safety and Heavy Metal Contaminations of Garri Sold in Benue, North-Central, Nigeria. African Journal of Biotechnology, 16, 1085-1091. https://doi.org/10.5897/AJB2016.15841

[38] Thomas, B.T., Ogunkanmi, L.A., Iwalokun, B.A. and Agu, G.C. (2017) Molecular Characterization and Strain Typing of Fungal Contaminants of Processed Manihot Esculenta Crantz ("Garri”) in Ogun State, Nigeria. Annals of Health Research, 3, 112-117.

[39] Tamura, K. and Nei, M. (1993) Estimation of the Number of Nucleotide Substitu- 
tions in the Control Region of Mitochondrial DNA in Humans and Chimpanzees. Molecular Biology and Evolution, 10, 512-526.

[40] Kumar, S., Stecher, G., Li, M., Knyaz, C. and Tamura, K. (2018) MEGA X: Molecular Evolutionary Genetics Analysis across Computing Platforms. Molecular Biology and Evolution, 35, 1547-1549. https://doi.org/10.1093/molbev/msy096

[41] Mofolorunsho, C.K., Iyaji, U.S. and Agboola, K. (2016) Mycoflora and Moisture Content of Garri Sold in Anyigba, Kogi State. British Journal of Applied Science and Technology, 15, 1-5. https://doi.org/10.9734/BJAST/2016/23670

[42] World Health Organization (WHO) (2018) Food Safety Digest: Aflatoxins. Department of Food Safety and Zoonoses, World Health Organization, Geneva.

[43] Gautier, M., Normand, A.-C. and Ranque, S. (2016) Previously Unknown Species of Aspergillus. Clinical Microbiology and Infection, 22, 662-669. https://doi.org/10.1016/j.cmi.2016.05.013

[44] Alastruey-Izquierdo, A., Alcazar-Fuoli, I. and Cuenca-Estrella, M. (2014) Antifungal Susceptibility Profile of Cryptic Species of Aspergillus. Mycopathologia. 178, 427-433. https://doi.org/10.1007/s11046-014-9775-z 